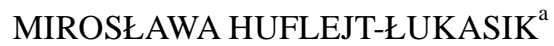 \\ WACŁAW BĄK \\ RAFAŁ STYŁA ${ }^{a}$ \\ KRZYSZTOF KLAJS ${ }^{\mathrm{c}}$ \\ ${ }^{a}$ Uniwersytet Warszawski \\ Wydział Psychologii \\ ${ }^{\mathrm{b}}$ Katolicki Uniwersytet Lubelski Jana Pawła II \\ Instytut Psychologii \\ ${ }^{\mathrm{c}}$ Polski Instytut Ericksonowski
}

\title{
ZMIANY W JA W TOKU PSYCHOTERAPII
}

\begin{abstract}
Artykuł poświęcony jest temu, jak proces i efekty psychoterapii mogą być analizowane i rozumiane $\mathrm{z}$ punktu widzenia badań nad pojęciem Ja. Na podstawie przeglądu literatury oraz własnego klinicznego doświadczenia autorzy starają się odpowiedzieć na następujące cztery pytania: (1) Na czym polega zmiana w toku psychoterapii w obrazie samego siebie? (2) Co zmienia się w obrazie Ja: struktura czy treść, czy i jedno, i drugie? Jakie są tu mechanizmy zmiany i warunki jej zachodzenia? (3) Jakie skutki dla funkcjonowania klienta przynoszą zmiany w Ja? (4) Czy możliwa jest zmiana w psychoterapii, której nie towarzyszyłaby zmiana w Ja? Aby odpowiedzieć na te pytania, dokonano przeglądu badań empirycznych dotyczących zmian w treści i strukturze Ja. Autorzy prezentują wyniki badań, odnosząc się np. do koncepcji takich, jak przedziałowość (Showers), złożoność Ja (Linville), przedmiotowa samoświadomość (Duval), możliwe Ja (Markus) czy klarowność obrazu Ja (Campbell). Ostatnia część artykułu prezentuje konkluzje dla praktyki. Wśród poruszonych kwestii jest znaczenie budowania pełnego i generalnie pozytywnego obrazu Ja - z tymi negatywnymi elementami, które przyczyniają się do pełnej i trafnej samowiedzy oraz wyznaczają kierunki rozwoju. Zauważono, że zmiana w treści Ja niesie $\mathrm{z}$ sobą zmianę $\mathrm{w}$ strukturze Ja, a ta ostatnia jest mocniej związana z przystosowaniem i zdrowiem psychicznym niż zmiana w treści Ja. Autorzy podkreślają ochronną rolę pozytywnych przyszłych obrazów Ja oraz zauważają, że warunkiem zdrowia psychicznego i efektywnej samoregulacji jest aktualna i szeroka samowiedza, a zatem psychoterapia $\mathrm{z}$ definicji zawiera zmianę w Ja.
\end{abstract}

Słowa kluczowe: pojęcie Ja, treść Ja, struktura Ja, skuteczność psychoterapii, proces psychoterapii.

Adres do korespondencji: MirosŁawa HuflejT-ŁUKASIK - Wydział Psychologii, Uniwersytet Warszawski, ul. Stawki 5/7, 00-183 Warszawa; e-mail: Miroslawa.Huflejt-Lukasik@psych.uw.edu.pl

Praca nad artykułem była współfinansowana ze środków BST nr 167815/2013 i nr 167843/2013, przydzielonych Wydziałowi Psychologii UW. 


\section{ASPEKTY POJECIA JA}

Pojęcie Ja pojawiło się $\mathrm{w}$ psychologii wraz $\mathrm{z}$ pracami Wiliama Jamesa (1890). Największy wzrost zainteresowania tą tematyką rozpoczął się w latach 70. XX wieku, gdy Ja zaczęto ujmować jako reprezentację poznawczą (Markus, 1977). Istnieje wiele definicji Ja (por. np. Leary i Tangney, 2003) i badane są różne obszary związane z Ja. Trudno jest nadać terminowi Ja jedno znaczenie. Nie ma też do końca jasnej odpowiedzi, gdzie kończą się granice Ja w psychice. W niniejszym artykule Ja definiowane jest jako reprezentacja poznawcza, czyli ustrukturalizowana wiedza o sobie samym (Markus, 1977). Ja, będąc systemem schematów poznawczych, selekcjonuje informacje $\mathrm{z}$ otoczenia, modyfikuje i przechowuje je w pamięci. Wpływa na zachowanie osoby, regulując jej działania. Wyznacza także plany i standardy zachowania. Działa jak swoista mapa, która umożliwia osobie orientację, a jednocześnie integruje jej funkcjonowanie. Obraz Ja kontroluje zatem przetwarzanie informacji na własny temat oraz pełni funkcje adaptacyjne i regulacyjne. Pozwala też na świadomą refleksję dotyczącą samego siebie. Ja jest dynamicznym systemem, który można opisać przez treść, strukturę, ale i zachodzące procesy, związane ze zmianami w Ja, także w relacjach z otoczeniem (Huflejt-Łukasik, 2010).

\section{Treść Ja}

Treści w Ja odnoszą się do tego, jaką jest się osobą, jakie przypisuje się sobie cechy i dyspozycje oraz jakie ma się przekonania dotyczące własnego wyglądu czy sposobu kształtowania relacji z innymi. W obrazie Ja zawarta jest duża ilość informacji, które osoba zebrała w toku całego swojego życia i które mogą podlegać modyfikacjom. W danym momencie aktywna jest tylko część informacji odnosząca się do własnej osoby. Nazwano ją roboczym obrazem Ja (working self-concept; Markus i Wurf, 1987). Elementy obrazu Ja różnią się dostępnością poznawczą. Pod wpływem pewnych warunków może ujawniać się dany obraz $\mathrm{Ja}, \mathrm{np}$. w trudnych sytuacjach robocze pojęcie Ja może być zdominowane przez negatywne treści. Koncepcja roboczego obrazu Ja pozwala zrozumieć zawartą w reprezentacji własnej osoby stałość, a także jej zmienność (Markus, 1977; Markus i Nurius, 1986).

$\mathrm{W}$ ramach koncepcji porządkujących treści w Ja istotne dla rozumienia zmian w Ja są te, które uwzględniają perspektywę czasową, w tym życiowe cele osoby (por. Huflejt-Łukasik, 2010). Jedną z czołowych koncepcji z tego zakresu jest teoria rozbieżności Ja (self-discrepancy theory; Higgins, 1987). Dzieli ona Ja 
na trzy odmienne obrazy: realny, idealny i powinnościowy. Porównanie realnego Ja z Ja wyznaczającym kierunek dążeń osoby, czyli Ja idealnym lub powinnościowym, wpływa na emocje i motywacje jednostki.

Kolejną jest koncepcja możliwych Ja (possible selves) Markus i Nurius (1986). Ja możliwe to bogaty zbiór wyobrażonych wizji siebie samego, które - choć bazują na doświadczeniach z przeszłości - mają wyraźne odniesienia do przyszłości (Erikson, 2007; Hoyle i Sherrill, 2006). Są one reprezentacją poznawczą nadziei, lęków i fantazji dotyczących własnej osoby. Osoba może tworzyć wiele Ja możliwych, nie tylko w odniesieniu do różnych obszarów funkcjonowania, lecz także w ramach tego samego obszaru. Ja możliwe obejmują przy tym zarówno odniesienia do stanów wartościowanych pozytywnie, jak i takich, których osoba wolałaby uniknąć. Ja możliwe zawierają zatem cele, które stawia przed sobą osoba - do osiągnięcia lub uniknięcia, czyli mówiąc inaczej, pozytywne i negatywne standardy Ja (Bak, 2014). Nie są to jednak zbiory abstrakcyjnych cech, ale zawsze mają charakter wysoce zindywidualizowanych i osobistych wyobrażeń własnej osoby, odnoszących się do konkretnej roli, sytuacji lub kontekstu.

Generalnie wyobrażenia przyszłych obrazów Ja - mieszczące się w pojęciu standardów Ja (np. Ja idealne, Ja powinnościowe) czy inaczej kierunków dla Ja (self-guides; Huflejt-Łukasik, 2010; Strauman, 1996) - są to te aspekty samowiedzy, które zawierając cele i dążenia osoby, wyznaczają kierunek rozwoju Ja. Obraz pożądanego Ja w przyszłości odzwierciedla zatem potencjalny rozwój osoby i zmiany.

\section{Struktura Ja}

Podstawowe cechy strukturalne Ja to: (1) zróżnicowanie, czyli jak wiele wymiarów w myśleniu o sobie używa osoba, oraz (2) integracja, czyli w jakim stopniu struktura jest jednością (Campbell, Assananad i Di Paula, 2003, 2004). W miarę rozwoju osoby słabnie hierarchia i powiązania między odmiennymi obszarami Ja, a zwiększa się integracja i powiązania między obszarami podobnymi (Marsh i Ayotte, 2003). Hierarchia w Ja oddaje to, w jakim stopniu dany obraz Ja jest ogólny czy specyficzny. Im wyżej dany aspekt Ja znajduje się w hierarchii, tym większe jego potencjalne znaczenie dla osoby. Poszczególne aspekty Ja na tych samych poziomach różnią się także ważnością w zależności od siły wpływu na aspekt wyższego poziomu lub na liczbę aspektów Ja, z którymi są powiązane (por. Carver i Scheier, 1998; Huflejt-Łukasik, 2010). 
Analizując tę problematykę, można wymienić następujące koncepcje i wskaźniki dotyczące struktury Ja:

(1) Wskaźnikiem zróżnicowania struktury Ja jest złożoność Ja (self-complexity; Linville, 1985, 1987). Jest ona tym większa, im więcej aspektów o różnej treści zawiera Ja i im więcej z nich jest niezależnych od siebie. Istotne jest tu także treściowe bogactwo każdego aspektu.

(2) Klarowność obrazu Ja (self-concept clarity) to przykład koncepcji opisującej integrację struktury Ja. Klarowność Ja opisuje zakres, w jakim zawartość indywidualnego obrazu Ja jest jasno i pewnie zdefiniowana, wewnętrznie spójna oraz stabilna w czasie (Campbell i in., 1996).

(3) Przedziałowość (inaczej tłumaczona jako szufladkowanie - compartmentalization) to przykład koncepcji opisującej strukturę Ja, przy czym trudno jednoznacznie określić, czy odnosi się bardziej do zróżnicowania czy integracji. Niektórzy uważają, że jest to koncepcja opisująca kolejny wymiar, na którym możemy opisywać strukturę Ja (Campbell i in., 2003). Przedziałowość określa stopień, w jakim cechy pozytywne i negatywne są przypisane do odrębnych grup opisujących ten sam aspekt Ja (Showers, 1992; Showers i Kling, 1996). Koncepcja ta opisuje myślenie zintegrowane ewaluacyjnie. Integracja ewaluacyjna oznacza tworzenie połączeń między opozycyjnie wartościowanymi informacjami. Osoba może zatem mieć odbiór siebie względnie niezależny od liczby posiadanych pozytywnych i negatywnych przekonań na własny temat. Kiedy jest ona podobna, znaczenie ma to, które informacje są ważne i jak są łączone (Huflejt-Łukasik, 2010).

\section{PYTANIA BADAWCZE}

W kontekście wykorzystania naukowej wiedzy o Ja nasuwają się następujące pytania dotyczące zmian Ja w toku psychoterapii:

1. Na czym polega zmiana w toku psychoterapii w obrazie samego siebie?

2. Co zmienia się w obrazie Ja: struktura czy treść, czy i jedno, i drugie? Jakie są tu mechanizmy zmiany i warunki jej zachodzenia?

3. Jakie skutki dla funkcjonowania klienta przynoszą zmiany w Ja?

4. Czy możliwa jest zmiana w psychoterapii, której nie towarzyszyłaby zmiana w Ja?

Odpowiedzi na te pytania pozwolą lepiej rozumieć istotę i mechanizmy oddziaływań psychoterapeutycznych. Mogą one być także pomocne w dookreśleniu standardu postępowania psychoterapeuty, w tym warunków koniecznych i pod- 
stawowych dla zmian w obrazie Ja oraz w dopasowaniu oddziaływań terapeutycznych do potrzeb i charakterystyki klienta.

\section{WYNIKI BADAŃ NAD ZMIANĄ JA}

Szukając odpowiedzi na powyższe pytania, będziemy odwoływać się do wyników badań odnoszących się do kwestii treści, struktury i dynamicznych procesów związanych z Ja.

\section{Ja a przystosowanie psychologiczne}

Badania ukazują, że miary zróżnicowania Ja i integracji Ja są od siebie niezależne (Campbell, Assananad i Di Paula, 2003; Suchańska i Worach, 2013). Jak się wydaje na podstawie przeglądu koncepcji i badań dotyczących Ja, hierarchiczna struktura Ja, czyli istnienie zintegrowanego centralnego obrazu Ja przy jednoczesnej złożoności reprezentacji odnoszących się do różnych sytuacji, najbardziej służy zdrowiu osoby (Showers i Zeigler-Hill, 2003). Zgodnie z rezultatami badań, centralny, znajdujący się na szczycie struktury obraz siebie jest najbardziej stabilny. Im bardziej peryferyczne aspekty Ja, czy będące niżej w hierarchii, tym obraz Ja staje się coraz bardziej specyficzny, zależny od sytuacji i podatny na zmiany. Taka struktura pozwala adaptować się do sytuacji, zachowując integrację Ja (por. Huflejt-Łukasik, 2010). Choć treść i struktura Ja są wzajemnie zależne (Campbell i in., 2003), to jednak struktura Ja jest bardziej związana z możliwościami adaptowania się osoby do zmian, jej przystosowaniem i zdrowiem psychicznym. Dzięki strukturze Ja oraz temu, iż jest ono w pewien sposób zorganizowane, istnieje ciągłość w Ja, czyli podwalina spójności Ja. Spójność, czyli integracja Ja, jest jedną z oznak zdrowia psychicznego umożliwia realizację indywidualnych celów i rozwój (Rogers, 1984).

Campbell i współpracownicy (2004) stwierdzają na podstawie przeglądu badań, że miary integracji Ja wykazują stałe związki z przystosowaniem. W przypadku miar zróżnicowania zależności takie występują, choć są bardziej złożone. W swoich badaniach Showers, Abramson i Hogan (1998) wykazali, iż zmiany w treści Ja oddają to, co zachodzi w życiu osoby, podczas gdy zmiany w strukturze Ja są związane z próbami zmniejszania skutków stresu. Z kolei większa przedziałowość (stopień, w jakim cechy pozytywne i negatywne są przypisane do odrębnych grup, opisujących ten sam aspekt Ja) w warunkach stresu pomaga izolować negatywne aspekty $\mathrm{Ja}$ - zmniejszać ich wpływ na samoocenę i nastrój. 
Rezultaty badań Linville (1987) pokazują, że organizowanie wiedzy o sobie w wielu relatywnie niezależnych elementach jest czynnikiem buforującym wpływ stresogennych wydarzeń życiowych oraz zapobiegającym depresji i innym zaburzeniom. Inni badacze doprecyzowali te rezultaty dowodząc, że istnieje związek między złożonością negatywnych aspektów Ja i brakiem przystosowania (Morgan i Janoff-Bulmann, 1994), niską samooceną, podatnością na stres i objawami psychopatologicznymi (Gara i in., 1993; Wollfolk, Novalany, Gara, Allen i Polino, 1995). Jednocześnie złożoność pozytywnych aspektów Ja stanowi czynnik, który buforuje szkodliwy wpływ stresu (Campbell i in., 2003, 2004).

\section{Zmienność i znaczenie standardów Ja}

Jeśli chodzi o Ja możliwe, w tym standardy Ja, to oprócz danych empirycznych ukazujących ich stabilność, są też takie, które wskazują na ich zmienność (Markus i Nurius, 1986). W sytuacji rozbieżności między Ja realnym i standardem osoba doświadcza emocjonalnego dyskomfortu, który motywuje do podjęcia prób zmniejszenia rozbieżności. W klasycznym ujęciu teorii przedmiotowej samoświadomości (Duval i Wicklund, 1972) standardy Ja były traktowane jako relatywnie niezmienne. Uważano, że z dwóch teoretycznie możliwych sposobów zmniejszenia rozbieżności bardziej prawdopodobna jest zmiana zachowania w kierunku dopasowania go do standardu niż zmiana standardu w kierunku większej zgodności z Ja realnym. Późniejsze badania sugerują jednak, że zmiana standardu jest możliwa. Jednak aby zmodyfikować standard (który może generować nadmierne i nierealistyczne oczekiwania wobec siebie i przez to być podłożem np. problemów depresyjnych), konieczne jest odwrócenie uwagi od obecnego, niesatysfakcjonującego stanu Ja i zogniskowanie uwagi na samym standardzie. Takie przekierowanie uwagi daje możliwość dokonania refleksji nad standardem, która z kolei może stymulować jego modyfikację (Duval i Lalwani, 1999; Silvia i Duval, 2001).

Badania dotyczące podatności przyszłych Ja na zmiany ukazują ich stabilność, ale też zmienność sytuacyjną. Frazier, Hooker, Johnson i Kaus (2000) prowadzili przez okres pięciu lat badania podłużne, których wyniki wskazują na stosunkowo dużą stabilność Ja możliwych. Z drugiej strony Strauss i Goldberg (1999) wykazały, że wejście w nową rolę życiową istotnie zmienia repertuar Ja możliwych. Badania te dotyczyły zmian w Ja w związku z wejściem w rolę ojca (pierwsze dziecko) i pokazały, że sytuacja ta nie tylko wpływa na wytworzenie się nowych Ja możliwych w tym nowym obszarze, lecz także promuje realne (obserwowane behawioralnie) zaangażowanie w wychowanie dziecka. Wynik ten 
jest spójny z tezą Markus i Nurius (1986), które podkreślają, że Ja możliwe są w dużym stopniu uwarunkowane kontekstem sytuacyjnym. Zmiana sytuacji promuje zmiany w repertuarze Ja możliwych, a to z kolei wpływa na adaptację do nowej sytuacji.

Rezultaty badań potwierdzają też, że bardziej podlegają zmianom treści Ja realnego niż Ja idealnego czy Ja powinnościowego. Przyszłe Ja - jako wyznaczające kierunek dla rozwoju - jest najbardziej stabilne w ramach Ja (np. Strauman, 1996). Ja realne zmienia się wraz $z$ nowymi doświadczeniami i informacjami. Jest to wymóg zdrowia, by treści w Ja były aktualizowane oraz uwewnętrznione i zintegrowane w ramach Ja (Rogers, 1984). Zapewniona jest zatem jednocześnie zmienność i stabilność Ja. Także wielkość i typ rozbieżności między Ja realnym a standardami Ja są względnie stałe w czasie, choć jednocześnie może się zmieniać dostępność poznawcza określonych treści w standardach Ja (Bąk i Gołębiowska, 2012; Strauman, 1996).

Co do znaczenia rozbieżności między Ja realnym a Ja idealnym, istnieją dwa odmienne poglądy. Według pierwszego rozbieżność jest wskaźnikiem dojrzałości i braku obronnych tendencji (Drożdżowicz, 2000). W drugim ujęciu rozbieżność traktowana jest przede wszystkim jako wskaźnik złego przystosowania (Harter, 1996; Higgins, 1987; Rogers, 1984). Badania wykazały na przykład, iż konstruktywne radzenie sobie ze stresem - przez działania w celu zmiany stresującej sytuacji i poszukiwanie pozytywnego wpływu zdarzenia na rozwój osoby związane jest z małą rozbieżnością w obrębie Ja (Poon i Lau, 1999). Pewna rozbieżność jest potrzebna, by wiedzieć, do czego dążyć. Jednak zbyt duża rozbieżność wiąże się z negatywnymi stanami, poczuciem beznadziejności i napięciem (Harter, 1996). Zrealizowanie określonego standardu skutkuje zmniejszeniem rozbieżności, ale jako że ludzie stawiają przed sobą nowe cele, taki stan nie trwa długo (Carver i Scheier, 1998; Silvia i Duval, 2001). Wydaje się zatem, że optymalna rozbieżność między bieżącym stanem Ja a możliwymi przyszłymi Ja zapewnia zarówno motywację, jak i dobrostan osoby.

Podobnie ważna w kontekście motywacji osoby do zmian jest równowaga między pozytywnymi a negatywnymi przyszłymi Ja. Pozytywne Ja możliwe (jaki chcę być) nadają kierunek dążeniom osoby i dają energię, budując nadzieję na przyszłość. Negatywne Ja możliwe (jaki nie chcę się stać), pokazując konsekwencje braku wytrwałości, wzmacniają motywację do unikania stanów niepożądanych (Oyserman i Markus, 1990). Rezultaty badań potwierdzają, że osoby mające wyższy poziom równowagi między pozytywnymi i negatywnymi standardami Ja wykazują większą liczbę podejmowanych działań ukierunkowanych na osiągnięcie tych standardów niż osoby mające niższy poziom równowagi 
(Niemiec, 2012). Badania ukazują też, iż osoby, u których przeważają procesy unikania, wykazują wyższy poziom lęku oraz więcej fizycznych dolegliwości niż osoby, u których przeważają dążenia ku osiągnięciom (Emmons, 1996; za: Carver i Scheier, 1998); przejawiają również pesymizm, niską samoocenę oraz depresję (Coats, Janoff-Bulman i Alpert, 1996).

Badania wskazują także, że pozytywne obrazy przyszłego Ja mogą pełnić funkcję ochrony Ja. W sytuacji porażki osoba może sięgnąć do pozytywnych Ja możliwych. Stwierdzono (Markus i Nurius, 1986), że osoby, które przeżyły w swoim życiu kryzys i nadal czuły, że są pod jego wpływem, miały nie tylko zaktywizowane negatywne Ja realne, ale też bardziej negatywne Ja możliwe. Natomiast osoby, które przeszły kryzys, ale były już poza jego wpływem, tworzyły pozytywne obrazy Ja możliwych i też oceniały je jako bardziej prawdopodobne niż osoby z grupy kontrolnej, które nie doświadczyły kryzysu. Możliwe są dwie interpretacje tych wyników. Osoby, które znajdują się w pozytywnym stanie po kryzysie, zawdzięczają to właśnie temu, iż kryzys już minął i dlatego są zdolne tworzyć pozytywne przyszłe obrazy Ja. Może być też tak, że to umiejętność budowania pozytywnych przyszłych Ja pozwoliła im wyjść z kryzysu.

\section{Zmiana Ja w toku psychoterapii}

Podstawowe szkoły psychoterapii (por. Grzesiuk, 2005) sugerują, iż efektywna psychoterapia powinna prowadzić m.in. do zwiększenia spójności i integracji Ja. Badania nad klarownością Ja (Campbell i in., 1996) nie dają jasnego obrazu wpływu psychoterapii na ten aspekt integracji Ja. Roepke i współpracownicy (2011) w badaniu z udziałem pacjentek z rozpoznaniem zaburzeń z pogranicza leczonych terapią dialektyczno-behawioralną lub oczekujących na terapię wykazali, że psychoterapia istotnie zwiększała poziom klarowności obrazu Ja. Inne badanie (Styła, Jędrasik-Styła i Krawczyk, w przygotowaniu) przeprowadzone $w$ grupie pacjentów $\mathrm{z}$ rozpoznaniem zaburzeń osobowości i nerwicy (uczestniczących w intensywnej psychoterapii grupowej, prowadzonej w sposób eklektyczny) wykazało, że klarowność obrazu Ja wzrasta wyłącznie u pacjentów, którzy początkowo charakteryzowali się niskim poziomem klarowności obrazu Ja. Zmiana klarowności obrazu Ja po psychoterapii wiązała się ze zmianą samooceny, objawów nerwicy i cech osobowości nerwicowej. Wyniki badań sugerują, że zmiana klarowności obrazu Ja pod wpływem psychoterapii może być zależna od początkowej integracji Ja pacjenta. Wynik ten jest zbieżny z rezultatami, iż klarowność obrazu Ja nie zmienia się u osób zdrowych nawet w momencie istotnych zmian życiowych, ale istnieje różnica w klarowności obrazu Ja między 
osobami zdrowymi a zaburzonymi. Pacjenci z depresją, lękiem czy ze schizofrenią mają niższą klarowność obrazu Ja (Huflejt-Łukasik, 2010).

Z kolei badania testujące teorię rozbieżności Ja (Higgins, 1987) pokazują, że $\mathrm{w}$ toku psychoterapii zachodzi istotne zmniejszenie rozbieżności między Ja realnym a Ja idealnym. W badaniach Straumana i współpracowników (2001) stwierdzono taki wynik u pacjentów z depresją po uczestnictwie w psychoterapii poznawczo-behawioralnej oraz interpersonalnej. Efektu takiego nie wykryto natomiast $\mathrm{w}$ przypadku rozbieżności między Ja realnym a Ja powinnościowym. Co ciekawe, u pacjentów depresyjnych, którzy nie brali udziału w psychoterapii, ale korzystali z farmakoterapii, również zaobserwowano poprawę objawową, ale nie wystąpiła ona w zakresie rozbieżności w systemie Ja.

Z kolei inne badanie (Philips, Raiford i El Batrawi, 1965) - testujące koncepcję Rogersa - sugeruje, że psychoterapia nie zwiększa podobieństwa między Ja realnym a Ja idealnym w całej grupie pacjentów. Truax, Schuldt i Wargo (1968) interpretują ten wynik tak, że psychoterapia prowadzi do wzrostu spójności między Ja realnym a Ja idealnym tylko u osób, dla których była ona skuteczna. Ich badania wskazują, że osoby, które z psychoterapii nie skorzystały, doświadczyły nasilenia napięcia i wzrostu złego przystosowania osobowościowego, mierzonego m.in. kwestionariuszem MMPI.

Także w innych badaniach spostrzeżono, że po udziale w skutecznej psychoterapii indywidualnej zmniejsza się rozbieżność między Ja realnym a Ja idealnym u pacjentów z zaburzeniami nerwicowymi i osobowości (Rakowska, 2006) oraz między Ja realnym a Ja powinnościowym (Elliott, 2008). Zmiany te korelowały ze zmniejszonym nasileniem depresji, niepokoju ogólnego oraz lęku społecznego. Zmniejszenie rozbieżności w Ja pod wpływem psychoterapii zaobserwowano też $\mathrm{w}$ grupie depresyjnych pacjentów w starszym wieku (Pemberton, 2009). Warto też dodać, że w psychoterapii zmianom podlegało Ja realne i zmniejszała się rozbieżność względem Ja idealnego tam, gdzie była ona duża (Rakowska, 2006). Nie dotyczyło to małych rozbieżności, które można rozumieć jako pełniące funkcje motywacyjne.

$\mathrm{Z}$ kolei osoby depresyjne pod wpływem informacji niosących z sobą zagrożenie dla Ja uruchamiały porównania między Ja realnym a Ja idealnym, pokazujące rozbieżność między nimi (Kinderman, Prince, Waller i Peters, 2003). Wynik ten można interpretować jako ochronną rolę przyszłych obrazów Ja. Badania informują także, że osoby z zaburzeniami psychicznymi cechują się sztywną strukturą Ja idealnego (mało scentralizowaną, $\mathrm{z}$ wieloma wzajemnie powiązanymi standardami Ja), która wiąże się z mniejszą elastycznością zmian w Ja idealnym i z występującym u osoby lękiem (Huflejt-Łukasik, 2010). 
Istnieją też dane dotyczące zmian w repertuarze Ja możliwych $\mathrm{w}$ trakcie przebiegu psychoterapii. Dunkel, Kelts i Coon (2006) badali liczbę Ja możliwych generowanych na kolejnych etapach zmiany. Odkryli, że wraz z kolejnymi stadiami psychoterapii (por. Prochaska i Norcross, 2006) najpierw następuje zdecydowane zwiększenie liczby Ja możliwych (co wiąże się z generowaniem możliwości rozwiązań problemu), a następnie, po decyzji o rozwiązaniu problemu, liczba możliwych Ja spada (gdyż realizowanie jednej z opcji wiąże się z rezygnacją z opcji alternatywnych). Ostatecznie wybrane Ja możliwe i jego treść staje się elementem Ja realnego. Na jego miejsce może oczywiście pojawić się zupełnie nowy zestaw Ja możliwych, które promują dalszy rozwój osoby.

\section{ZMIANY JA W TOKU PSYCHOTERAPII W ŚWIETLE BADAŃ A WNIOSKI DLA PRAKTYKI}

Przedstawione koncepcje i badania wskazują kierunki zmiany Ja, które są skojarzone z pozytywnymi skutkami dla funkcjonowania jednostki. Proponowane wskazówki dla działań w psychoterapii należy traktować jako hipotetyczne oraz jako źródło inspiracji i zrozumienia tego, co może dziać się w procesie terapeutycznym.

I tak koncepcje i badania ukazują znaczenie pełnej samowiedzy: jaką jestem osobą, jakie są moje cechy - pozytywne i negatywne aspekty obrazu siebie, ważne cele, także to, jakie działania mogę podejmować. Trafna samowiedza pozwala na bycie aktywnym, podejmowanie bardziej dopasowanych decyzji i zachowań uwzględniających własne możliwości, potrzeby i wymagania otoczenia. Badania informują też, że zmiana treści w Ja pociąga za sobą zmianę w strukturze Ja, czyli oddziaływania w toku psychoterapii ukierunkowane na zmianę postrzegania siebie pociągają ze sobą zmianę w strukturze Ja (np. zwiększając złożoność i zróżnicowanie poznawczych reprezentacji własnej osoby).

Zmiana struktury w większym stopniu niż zmiana treści wiąże się z przystosowaniem i zdrowiem psychicznym osoby. Co więcej, zmiana w strukturze umożliwia dalej zmianę treści nawet tych aspektów obrazu Ja, nad którymi nie pracujemy bezpośrednio w toku psychoterapii. Podstawą zmian w strukturze Ja jest bowiem także zgodność ewaluatywna (Vallacher i Nowak, 2004). Vallacher i Nowak przeprowadzili serię symulacji komputerowych odzwierciedlających samoorganizację struktury Ja i stwierdzili, że nawet jeśli aspekty Ja nie są powiązane pod względem treści, zestawione ze sobą, będą zmieniać znak. Jeżeli element otoczony był przez inne elementy o znaku przeciwnym, wtedy jego znak 
zmieniał się, dostosowując do otaczających elementów. Można więc postulować, że dodając $\mathrm{w}$ toku psychoterapii pozytywne elementy do postrzegania siebie przez pacjenta, zmieniamy potencjalnie też te negatywne treści, nad którymi bezpośrednio nie pracowaliśmy.

Struktura Ja wyznacza też dostępność treści Ja, chroniąc przed negatywnymi skutkami negatywnych zdarzeń. Zróżnicowanie obrazu siebie, powiązane z określonym kontekstem sytuacyjnym, a także oddzielenie pozytywnych i negatywnych cech danego aspektu Ja zapobiega generalizacji, jeśli pod wpływem zdarzeń życiowych naruszona zostaje część obrazu siebie. Wydaje się, że uświadamianie sobie zarówno pozytywnych, jak i negatywnych aspektów Ja, jednak $\mathrm{z}$ naciskiem na tworzenie pozytywnej i zróżnicowanej reprezentacji Ja, będzie nie tylko buforować negatywne skutki stresu, lecz także tworzyć lepszą samowiedzę.

W toku psychoterapii istotna jest zatem praca nad tworzeniem pełnego, generalnie pozytywnego obrazu siebie, z uwzględnieniem tych aspektów negatywnych, które przynoszą ze sobą pełniejszą samowiedzę i nadają kierunek rozwojowi osoby. Badania wszak wskazują, że równowaga między pozytywnymi i negatywnymi wyobrażeniami przyszłych, możliwych Ja skutkuje większą aktywnością w osiąganiu pożądanych dla Ja celów. Niezależnie od tego należy zaakcentować znaczenie pozytywnego obrazu przyszłego Ja, takiego jak np. Ja idealne, które może pełnić ochronną, stabilizującą rolę w ramach Ja również w obliczu trudności czy kryzysów, ponieważ zawiera istotne cele, z którymi w sytuacji kryzysu osoba może się utożsamić. Co więcej, według koncepcji Ja możliwych osoba może w sytuacji kryzysu tworzyć dodatkowe wyobrażenia pozytywnego przyszłego obrazu siebie, co także ma funkcję ochronną. Ta zależność wymaga jednak jeszcze weryfikacji empirycznej.

W kontekście pracy psychoterapeutycznej, polegającej na poznawaniu samego siebie, istotne jest odkrycie, które aspekty są centralne dla osoby i mają większą wagę niż inne. Badania wskazują, że obraz Ja ulega zmianom pod wpływem doświadczeń. Pomaga to adaptować się do zmian, a także rozwijać. Jednocześnie posiadanie centralnych dla Ja treści stabilizuje poczucie tożsamości. Wiemy, że taką właśnie funkcję pełni Ja idealne i że to Ja realne zmienia się w toku udanej psychoterapii, zmniejszając różnice z Ja idealnym. Prawdopodobnie w toku udanej psychoterapii klient odkrywa, że jest bliżej swojego ideału, niż myślał, bądź podejmuje aktywności, by tak się stało. Choć nie ma aktualnie bezpośrednich danych empirycznych, należy też uwzględnić sytuację, w której nierealistyczne Ja idealne służy ochronie tożsamości, a zmiana w psychoterapii będzie polegała 
na budowaniu stabilnego, pozytywnego obrazu siebie, a także na urealnieniu Ja idealnego (por. Huflejt-Łukasik, 2010).

Wiemy, że w pewnym stopniu i w pewnych warunkach Ja możliwe także podlegają zmianie. Zatem zmiana w psychoterapii opierać się może na eksploracji możliwych przyszłych wizji własnej osoby. Jeśli Ja możliwe wpływają na zmiany funkcjonowania osoby, to otwiera się pole do wykorzystania wiedzy o Ja możliwych jako inspiracji do interwencji terapeutycznych poszerzających repertuar możliwych wizji siebie klienta. Odwołując się do tej idei, można zachęcać klienta do wchodzenia w nowe, nieznane wcześniej konteksty, co może przygotować go do nowych aktywności i ról życiowych.

Z kolei jeśli źródłem problemów jest nierealistyczny standard Ja, to wysiłki zmierzające do tego, żeby mu sprostać, będą nieefektywne, a mogą być wręcz szkodliwe. Interwencja terapeutyczna, która polegałaby na poddaniu refleksji stawianych sobie oczekiwań, może doprowadzić do ich zmiany i poprawy stanu psychicznego osoby bez zmiany zachowania (por. Duval i Lalwani, 1999). Oczywiście warunkiem skuteczności takiej interwencji jest zadbanie o bezpieczeństwo emocjonalne klienta, stworzenie podstaw do tej zmiany. Wyniki badań wskazują bowiem, że nierealistyczne standardy Ja mogą służyć ochronie integracji obrazu siebie, nawet jeśli klient ma świadomość, że osiągnięcie celu jest mało realistyczne (por. Huflejt-Łukasik, 2010).

Istotne jest, by w zmianach Ja istniała równowaga w procesach różnicowania i integracji. Zapobiega ona negatywnej fragmentacji Ja albo zbyt silnej integracji, która utrudniałaby pożądaną zmianę (Huflejt-Łukasik, 2010). W pewnych warunkach autorefleksja (także w toku psychoterapii) może powodować zmniejszenie spójności Ja (Vallacher i Nowak, 2004). Jeśli do Ja zostanie włączony ważny, choć nacechowany odmienną wartością, element, to wpłynie on na oboczne elementy, zwiększając obszar o innej wartości. Powodowałoby to powstawanie ob.szarów Ja nacechowanych ambiwalencją. Wyniki badań i przykłady z psychoterapii pokazują jednak, iż taka sytuacja może sprzyjać stopniowej zmianie negatywnego obrazu własnej osoby na bardziej pozytywny. Osoby depresyjne mają mało dostępnych pozytywnych aspektów w swoim obrazie Ja. Uwalniają się od depresji, jeśli to pozytywne aspekty Ja stają się dla nich centralne (Pelham, 1991).

Czy możliwa jest zmiana w psychoterapii, której nie towarzyszyłaby zmiana w Ja? Jeśli wymogiem zdrowia psychicznego i skutecznej samoregulacji jest aktualna, szeroka samowiedza, uwzględniająca nowe doświadczenia, to psychoterapia $\mathrm{z}$ założenia wiąże się ze zmianą Ja, nawet jeśli $\mathrm{w}$ terapii świadomie oddziałujemy na inne aspekty funkcjonowania osoby. Niezależnie od celu psychoterapii psychoterapeuta powinien mieć świadomość tego, jaki wpływ mają pro- 
ponowane oddziaływania terapeutyczne na zmiany w Ja klienta. Niezależnie bowiem od intencji psychoterapeuty i klienta, skuteczna psychoterapia zawsze wiąże się ze zmianą zarówno w zakresie treści (bardziej adaptacyjna zawartość schematów Ja), jak i struktury Ja (por. Styła, 2012). Zmiana w zakresie treści Ja może mieć charakter drobnej modyfikacji lub głębokiej restrukturyzacji. Oba rodzaje zmiany - o ile mają charakter adaptacyjny - powinny ostatecznie prowadzić do wzrostu integracji struktury Ja, rozumianej jako jasno i pewnie zdefiniowany, wewnętrznie spójny oraz stabilny w czasie obraz Ja. Jednak zarówno te prawidłowości, jak i inne dotyczące zmian w Ja w toku psychoterapii wymagają szerokiej weryfikacji empirycznej. Tematyka zmian Ja wydaje się podstawowa w kontekście psychoterapii. Istniejące koncepcje i badania z obszaru psychologii poznawczej i osobowości dostarczają danych, by wyjaśniać, co dzieje się w toku psychoterapii, i pozwalają wskazać pożądane oddziaływania. Mało jednak jest badań, które ukazywałyby mechanizmy zmiany Ja i jej dynamikę w kontekście prowadzonej psychoterapii, czyli obszary i głębokość zmiany Ja zależnie od celów i podejmowanych działań w psychoterapii. Ten kierunek badań należy zatem uznać za najbliższy krok w zgłębianiu tej tematyki. Kolejny mógłby dotyczyć sprawdzania skuteczności określonych oddziaływań ukierunkowanych na zmiany Ja wraz z przypisanymi im skutkami.

\section{LITERATURA CYTOWANA}

Bak, W. (2014). Self-standards and self-discrepancies. A structural model of self-knowledge. Current Psychology, 33, 155-173.

Bąk, W. i Gołębiowska, N. (2012). Stabilna struktura niestabilnych treści. Statość i zmienność w samowiedzy. Plakat prezentowany na IX Zjeździe Polskiego Stowarzyszenia Psychologii Społecznej, Sopot.

Campbell, J. D., Assananad, S. i Di Paula, A. (2003). The structure of self-concept and its relation to psychological adjustment. Journal of Personality, 71, 115-140.

Campbell, J. D., Assananad, S. i Di Paula, A. (2004). Cechy strukturalne pojęcia Ja a przystosowanie. W: A. Tesser, R. B. Felson i J. M. Suls (red.), Ja i tożsamość (s. 70-88). Gdańsk: Gdańskie Wydawnictwo Psychologiczne.

Campbell, J. D., Trapnell, P. D, Heine, S. J., Katz, I. M., Lavallee, L. F. i Lehman, D. R. (1996). Self-concept clarity: Measurement, personality correlates, and cultural boundaries. Journal of Personality and Social Psychology, 70, 141-156.

Carver, C. S. i Scheier, M. F. (1998). On the self-regulation of behavior. Cambridge: Cambridge University Press.

Coats, E. K., Janoff-Bulman, R. i Alpert, N. (1996). Approach versus avoidance goals: Differences in self-evaluation and well-being. Personality and Social Psychology Bulletin, 22, 1057-1067.

Drożdżowicz, L. (2000). Struktura „Ja” w schizofrenii. Psychoterapia, 115(4), 21-34. 
Dunkel, C. S., Kelts, D. i Coon, B. (2006). Possible selves as mechanisms of change in therapy. W: C. Dunkel i J. Kerpelman (red.), Possible selves. Theory, research and applications (s. 187-204). New York: Nova Science Publishers.

Duval, T. S. i Lalwani, N. (1999). Objective self-awareness and causal attributions for self-standard discrepancies: Changing self or changing standards of correctness. Personality and Social Psychology Bulletin, 25, 1220-1229.

Duval, T. S. i Wicklund, R. A. (1972). A theory of objective self-awareness. New York: Academic Press.

Elliott, K. L. (2008). The relation of self-discrepancy to anxiety and depression as psychotherapy change measures. Dissertation Abstracts International: Section B: The Sciences and Engineering, 68(9-B), 6301.

Erikson, M. G. (2007). The meaning of the future: Toward a more specific definition of possible selves. Review of General Psychology, 11, 348-358.

Frazier, L. D., Hooker, K., Johnson, P. M. i Kaus, C. R. (2000). Continuity and change in possible selves in later life: A 5-year longitudinal study. Basic and Applied Social Psychology, 22, 237-243.

Gara, M. A., Woolfolk, R. L., Cohen, B. D., Goldston, R. B., Allen, L. A. i Novalany, J. (1993). Perception of self and other in major depression. Journal of Abnormal Psychology, 102, 93-100.

Grzesiuk, L. (red.) (2005). Psychoterapia. Teoria. Warszawa: Eneteia.

Harter, S. (1996). Historical roots of contemporary issues involving self-concept. W: B. A. Bracken (red.), Handbook of self-concept. Developmental, social, and clinical considerations (s. 1-37). New York: John Wiley \& Sons.

Higgins, E. T. (1987). Self-discrepancy: A theory relating self and affect. Psychological Review, 94, 319-340.

Hoyle, R. H. i Sherrill, M. R. (2006). Future orientation in the self-system: Possible selves, self-regulation, and behavior. Journal of Personality, 74, 1673-1696.

Huflejt-Łukasik, M. (2010). Ja i procesy samoregulacji: różnice między zdrowiem a zaburzeniami psychicznymi. Warszawa: Wydawnictwo Naukowe Scholar.

James, W. (1890). The principles of psychology. New York: Holt.

Kinderman, P., Prince, S., Waller, G. i Peters, E. (2003). Self-discrepancies, attentional bias and persecutory delusions. British Journal of Clinical Psychology, 42, 1-12.

Leary, M. R. i Tangney, J. P. (2003). The self as an organizing construct in the behavioral and social sciences. W: M. R. Leary i J. P. Tangney (red.), Handbook of self and identity (s. 3-14). New York: The Guilford Press.

Linville, P. W. (1985). Self-complexity and affective extremity: Don't put all of your eggs in one cognitive basket. Social Cognition, 1, 94-120.

Linville, P. W. (1987). Self-complexity as a cognitive buffer against stress-related illness and depression. Journal of Personality and Social Psychology, 52, 663-676.

Markus, H. (1977). Self-schemata and processing information about the self. Journal of Personality and Social Psychology, 35, 63-78.

Markus, H. i Nurius, P. (1986). Possible selves. American Psychologist, 41, 954-969.

Markus, H. i Wurf, E. (1987). The dynamic self-concept: A social psychological perspective. Annual Review of Psychology, 38, 299-337. 
Marsh, H. W. i Ayotte, V. (2003). Do multiple dimensions of self-concept become more differentiated with age? The differential distinctiveness hypothesis. Journal of Educational Psychology, 95, 687-706.

Morgan, H. J. i Janoff-Bulmann, R. (1994). Positive and negative self-complexity: Patterns of adjustment following traumatic versus non-traumatic life experience. Journal of Social and Clinical Psychology, 13, 63-85.

Niemiec, M. (2012). Pozytywne i negatywne standardy Ja a dziatania podejmowane $w$ celu ich osiagnięcia oraz dobrostan psychiczny osoby. Niepublikowana praca magisterska. Uniwersytet Warszawski, Wydział Psychologii, Warszawa.

Oyserman, D. i Markus, H. R. (1990). Possible selves and delinquency. Journal of Personality and Social Psychology, 59, 12-125.

Pelham, B. W. (1991). On the benefits of misery: Self-serving biases in the depressive self-concept. Journal of Personality and Social Psychology, 61, 670-681.

Pemberton, E. D. (2009). The relationship between self-discrepancy, depression severity, and psychotherapy treatment in depressed older adults. Dissertation Abstracts International. Section B: The Sciences and Engineering, 69(8-B), 5047.

Phillips, E. L., Raiford, A. i El-Batrawi, S. (1965). The Q sort reevaluated. Journal of Consulting Psychology, 29, 422-425.

Poon, W.-T. i Lau, S. (1999). Coping with failure: Relationship with self-concept discrepancy and attributional style. The Journal of Social Psychology, 139, 639-653.

Prochaska, J. O. i Norcross, J. C. (2006). Systemy psychoterapeutyczne. Analiza transteoretyczna. Warszawa: Instytut Psychologii Zdrowia PTP.

Rakowska, J. M. (2006). Sukces i porażka terapii krótkoterminowej. Warszawa: Wydawnictwo Naukowe Scholar.

Roepke, S., Schröder-Abé, M., Schütz, A., Jacob, G., Dams, A., Vater, A., Rüter, A., Merkl A., Heuser I. i Lammers C. H. (2011). Dialectic behavioural therapy has an impact on self-concept clarity and facets of self-esteem in women with borderline personality disorder. Clinical Psychology and Psychotherapy, 18, 148-158.

Rogers, C. (1984). Teoria terapii osobowości i relacji interpersonalnych rozwinięta w oparciu o podejście skoncentrowane na kliencie. Nowiny Psychologiczne, 2-3, 1-91.

Showers, C. J. (1992). Evaluative integrative thinking about characteristics of the self. Personality and Social Psychology Bulletin, 18, 719-729.

Showers, C. J., Abramson, L. Y. i Hogan, M. E. (1998). The dynamic self: How the content and structure of the self-concept change with mood. Journal of Personality and Social Psychology, $75,478-493$.

Showers, C. J. i Kling, K. C. (1996). Organization of self-knowledge: Implications for recovery from sad mood. Journal of Personality and Social Psychology, 70, 578-590.

Showers, C. J. i Zeigler-Hill, V. (2003). Organization of self-knowledge: Features, functions, and flexibility. W: M. R. Leary i J. P. Tangney (red.), Handbook of self and identity (s. 47-67). New York: The Guilford Press.

Silvia, P. J. i Duval, T. S. (2001). Objective self-awareness theory: Recent progress and enduring problems. Personality and Social Psychology Review, 5, 230-241.

Strauman, T. J. (1996). Stability within the self: A longitudinal study of the structural implications of self-discrepancy theory. Journal of Personality and Social Psychology, 71, 1142-1153. 
Strauman, T. J., Kolden, G. G., Stromquist, V., Davis, N., Kwapil, L., Heerey E. i Schneider, K. (2001). The effects of treatments for depression on perceived failure in self-regulation. Cognitive Therapy and Research, 25, 693-712.

Strauss, R. i Goldberg, W. A. (1999). Self and possible selves during the transition to fatherhood. Journal of Family Psychology, 13, 244-259.

Styła, R. (2012). Change in self-concept differentiation after psychotherapy and its relation to psychological maladjustment. Psychological Reports, 110, 397-402.

Styła, R., Jędrasik-Styła, M. i Krawczyk, K. (w przygotowaniu). Does the self-concept clarity change after psychotherapy? How is it related to psychological maladjustment?

Suchańska, A. i Worach, A. (2013). Złożoność koncepcji siebie a poczucie tożsamości. Roczniki Psychologiczne, 16(2), 199-215.

Truax, Ch. B., Schuldt, W. J. i Wargo, D. G. (1968). Self-ideal concept congruence and improvement in group psychotherapy. Journal of Consulting and Clinical Psychology, 32, 47-53.

Vallacher, R. R. i Nowak, A. (2004). Krajobrazy autorefleksji: mapowanie szczytów i dolin oszacowań własnej osoby. W: A. Tesser, R. B. Felson i J. M. Suls (red.), Ja i tożsamość (s. 43-69). Gdańsk: Gdańskie Wydawnictwo Psychologiczne.

Wollfolk, R. L., Novalany, J., Gara, M. A., Allen, L. A. i Polino, M. (1995). Self-complexity, self-evaluation, and depression: An examination of form and content within the self-schema. Journal of Personality and Social Psychology, 68, 1108-1120. 